\title{
Court asked to halt inquiry into psychologist's suicide
}

Montreal. Quebec's Superior Court has been asked to suspend an inquiry ordered by McGill University into the death of the neuropsychologist Justine Sergent, who committed suicide last April (see Nature $369,176 ; 1993)$. It has also been asked to remove the lawyer that the university appointed to carry out its inquiry.

Both requests have come from Michael Pesner, the accountant charged with settling Sergent's estate, whose remit includes protecting Sergent's reputation. He claims that Caspar Bloom, the president of the Montreal bar who is conducting the inquiry, the university, and his son is a resident physician at a McGill teaching hospital.

The university refuses to comment on the petition until a judge hears a request for a temporary injunction, due to take place this week. In addition to Bloom's inquiry into McGill's handling of the Sergent case, a scientific audit of her work is under way and is expected to be completed by the end of the year.

Sergent and her husband Yves committed suicide after publication of a newspaper article triggered by an anonymous letter that revealed that she had been reprimanded by tions on the use of human subjects in experiments. She was contesting the reprimand.

As part of Pesner's petition, Sergent's suicide note was published for the first time. In it she gave her version of the dispute with the ethics committee of the Montreal Neurological Institute. "I have been accused of breaking rules," she wrote. "The ethics committee of the Montreal Neurological Institute [MNI] considered that I did not abide by the rules because I carried out a study on reading musical notation with positron emission tomography [PET].'”

She says that, as the ethics committee had approved experiments using PET technology in subjects with faces, letters or words should not do so because he is being paid by the university for failing to observe regula-

as stimuli, she "did not consider putting subjects at more risk by exposing them to a different type of visual information".

Her note also claimed that the ethics committee was not competent to decide whether or not she broke a rule because it did not follow guidelines laid down by the Medical Research Council of Canada. These, she said, called for at least one expert in her field to sit on the committee evaluating her research, but she claimed that none did so. (A spokeswoman for the university said she was unable to verify whether such an expert had participated in the committee's work.)

Sergent also admitted in her note to altering the telephone numbers of some subjects. But she said that she did this because the consent forms signed by the subjects stipulate that everything about participation in a study is confidential.

"I had received complaints from subjects participating in earlier studies that someone, claiming to be either from 'security at McGill' or from the 'director's office' was calling them and asking them questions about the various tasks they had been performing during my PET studies," she said.

"I therefore decided to ensure the confidentiality of the subjects by altering the telephone number on the official form which I did in their presence, while keeping the correct number in my files."

Publication of the newspaper story had discredited both her work and her career in a way "which I cannot tolerate", she said. Before the publication of the article, she had hoped that the audit of her research would clear her name, as the letter had raised doubts "about my honesty as a scientist".

But she said she could not be assured that she would be treated fairly by the MNI, claiming that the institute's director had withheld from an evaluation committee information she had sent to him in connection with a request to be considered for a promotion.

David Spurgeon

\section{Salk Institute president is replaced}

Washington. Brain Henderson has resigned as president and chief executive of the Salk Institute, the biomedical research centre, based in San Diego, California founded by polio vaccine pioneer Jonas Salk.

Henderson left the Institute suddenly in October, returning full-time to his cancer epidemiology research at the University of Southern California. He denies reports that he was fired: "The challenge of fund-raising for the institute and doing science at the same time was tougher than
I thought," he says. "I realised I could no longer do both."

The trustees of the prestigious institute moved quickly to split Henderson's function, and last week named Charles Massey as new chief executive officer and Francis Crick - winner of the Nobel Prize with James Watson for discovering the DNA double helix - as president.

The Salk Institute, which specialises in molecular biology, genetics and neuroscience, has fifty senior faculty and eight hundred support staff. Colin Macilwain

\section{Highway in the sky comes to the aid of India's scientists}

New Delhi. Indian scientists, frequently frustrated by the high cost of travel and subscriptions to foreign journals, are turning enthusiastically to a high-speed, satellitebased information highway with which they can communicate instantly and free of charge between themselves and counterparts on INTERNET in 150 countries.

Commissioned by the National Informatics Centre (NIC), the data-link now connects 15 cities. NIC's director-general, N. Seshagiri, says it will link a total of 70 cities and towns--serving more than 10,000 users — by the end of 1996.

Voice, texts, graphics and photographs can be transmitted over the network at 2.2 million bits per second (b.p.s.), a speed that Seshagiri claims conforms to the standard international definition of an 'information highway'.

Seshagiri says that scientists can use the highway to send and receive electronic mail and news of conferences and seminars, to transmit research papers for publication, and to hold video conferences. Bibliographic information on 15,000 journals will eventually be available, while scientists will also be able to obtain full texts of articles from 1,000 journals, including graphics.

Scientists from 2,000 selected academic and research institutions have already been invited to use this facility. By the middle of 1996, the network's services will be available "at the doorsteps of all of India's 8,000 research, educational and medical institutions", says Seshagiri.

The overall cost of the highway will be less than $£ 10$ million. Seshagiri says this was achieved by avoiding expensive fibre optics, by using NIC's existing satellitebased network NICNET as a backbone, and by limiting its applications. "We have designed our highway for scientists and businessmen - not to provide video on demand or for shopping from home," he says.

NICNET was set up in 1988 and links government computers in 500 cities and towns through the INSAT domestic satellite, using nearly 700 roof-top antennas. These operate in the C-band ( $5 \mathrm{MHz})$, sending messages at 9,600 b.p.s., a speed that is too slow for multimedia applications.

Seshagiri says that part of NICNET, linking important centres, has been turned into an information highway by installing highspeed satellite terminals operating at 36 $\mathrm{MHz}$. As INSAT does not carry any transponders operating in the relevant wave band, the highway relies on an Intelsat satellite. But NIC will switch to the domestically produced INSAT-2C - with an appropriate transponder - when it is launched in 1995.

K. S. Jayaraman 